\title{
Yaygın Eğitim Kurumu Öğretmenlerinin Müdür Algıları: İBB İsmek Örneği
}

Sümeyye Kuşakc1 ${ }^{1}$, Esra Kırtan ${ }^{2}$

\begin{abstract}
Özet
Kompleks fenomenleri daha yalın ve anlaşılabilir bir biçimde ortaya koyan metaforlar son yıllarda sosyal bilimler araştırmalarında oldukça rağbet görmektedir. $\mathrm{Bu}$ nitel araştırma kapsamında İstanbul Büyükşehir Belediyesi Sanat ve Meslek Eğitimi Kurslarında (ISSMEK) görev yapan öğretmenlerin müdür kavramına ilişkin zihinsel algıları metaforlar aracılığ $\breve{1}_{1}$ ile tespit edilmek istenmiştir. Araştırmaya İSMEK bünyesinde farklı branşlarda istihdam edilen 180 öğretmen katılmıştır. İlgili alan yazınında daha çok yaygın eğitim kurumlarında uygulandığı gözlemlenen bu yaklaşım, bir yaygın eğitim kurumu olan İSMEK'te hâkim olan yönetici algısını ve yönetim uygulamalarını değerlendirmeyi hedeflemiştir.

Araştırmanın sonucunda 119 metafor, üç ana ve 22 alt kategoriye ayrılmıştır. Öğretmenlerin mevcut müdürlerine yönelik olumlu ve olumsuz algılarının yanı sıra, ideal müdür algıları da keşfedilmiştir. Beklenen / olması gereken müdür davranışı algısına ilişkin yedi alt kategori şu şekilde sıralanmaktadır: Geliştiren, Değer Veren / Özen Gösteren, İyi Davranan / Iyi Hissettiren, Koruyan, Adaletli, Sertve Araci. Mevcut müdür davranışına ilişkin pozitifmetafor kategorileri, Adaletli / Şeffaf, Gelişstiren, Iyi Davranan / Iyi Hissettiren, Koruyan, Temiz / Düzenli, Aracı ve Muktedir iken; sekiz negatif metafor kategorileri ise şunlardır: Kibirli, Agresif, Buyurgan, Seviyesiz, Rahatsız Eden, Değissken, Aceleci ve Cezalandıran.
\end{abstract}

1 Yetkilendirilmiş yazar: İbn Haldun Üniversitesi, Yönetim Bilimleri Fakültesi, İstanbul, Turkey, sumeyyearslanoglu@gmail.com, ORCID ID: 0000-0002-9493-2591

2 İbn Haldun Üniversitesi, esraakan34@gmail.com, ORCID ID: 0000-0002-9493-2591 
Araştırmamız kapsamında ortaya çıkan mevcut müdür algısına ilişkinmetaforların yaklaşık olarak \% 60’1 pozitif, geri kalanı ise negatif içeriklidir. Pozitif metaforların arasında iyi davranan / iyi hissettiren ve geliştiren müdür davranışı öne çıkmaktadır. Negatif metaforlara baktığımızda ise, birinci sırayı rahatsız eden lider davranışları almıştır. Onu agresifve değişken müdür davranışları izlemektedir. Çalışmamız kapsamında elde ettiğimiz kategoriler arasında, öncelikli olarak Koruyan, Geliştiren, Muktedir ve Buyurgankategorileri daha önceki çalışmalarla da desteklenmektedir.

\title{
Anahtar Kelimeler
}

İsmek, Yaygın Eğitim, Fenomenoloji, Metafor, Müdür, Öğretmen.

\section{Perceptions of Teachers at Common-Public Education Institutions on Principal: The Case of İBB-İsmek}

\author{
Sümeyye Kuşakc1, Esra Kırtan
}

\begin{abstract}
Metaphors that helps to demonstrate complex phenomena in a simpler and understandable way have been very popular in social science researches recently. Within the scope of this qualitative study, teachers working at Istanbul Metropolitan Municipality Art and Vocational Education Courses (İSMEK) were asked to describe the behaviors of principals through metaphors. 180 teachers employed in different branches within ISMEK participated into the study. It was aimed to discover the perception of teachers on manager and management practices at a informal education institution through the example of ISMEK.

According to the results of the study, 119 metaphors are divided into three main and 22 sub-categories. In addition to the positive and negative perceptions of teachers towards their current principals, their perceptions on ideal principal were also discovered. The seven sub-categories related to the perception of expected / required principal behavior are listed as follows: Promoter, Respectful / Attentive, Benevolent, Protector, Fair, Though and Mediator. While the positive metaphor categories related to existing principal behavior are: Fair / Transparent, Promoter, Benevolent, Protector, Clean and Tidy, Mediator and Powerful; the eight negative metaphor categories are: Arrogant, Aggressive, Bossy, Ill-bred, Annoying, Ambivalent, Hasty and Discipliner.

Moreover, approximately $60 \%$ of the metaphors developed by the teachers on their current managers are positive. Among the positive categories, Benevolent and Promoter principal come to the forefront. On the negative side, Annoying manager is on the first rank followed by Aggressive and Ambivalent ones. Finally, among the categories
\end{abstract}


acquired by the study, the categories of Protecting, Promoter, Powerful and Bossy are supported by previous studies.

\section{Keywords}

İSMEK, Non-formal Education, Phenomenology, Metaphor, Manager, Teacher

\section{تصور المعلمين في مؤسسات التعليم العام حول الإدارة: حالة IBB-ISMEK}

\section{سمية كثاكجى اسراء كرتان \\ الخلاصة}

الاستعار ات التي تساعد على إظهار الظو اهر المعقدة بطريقة مفهومة و بسيطة حازت شعبية كبيرة في أبحاث

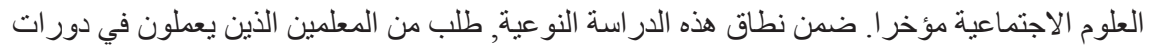

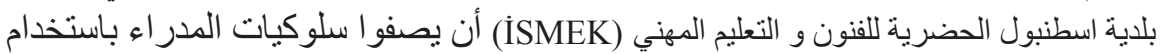

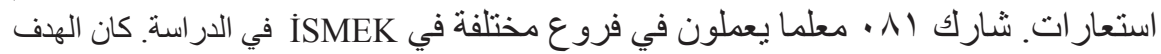

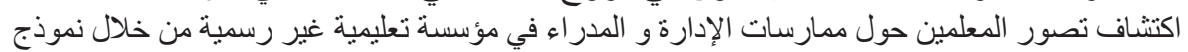
.ISMEK

وفقا لنتائج الدراسة, تم تقسيم 119 مجاز ا إلى ثلاث فئات رئيسية و r ب فئة فر عية. بالإضافة إلى الئ التصورات الإيجابية و السلبية للمعلين تجاه مديريهم الحالبين, تم اكتشاف تصور اتهم للمدير

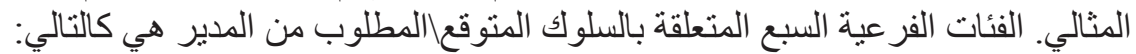

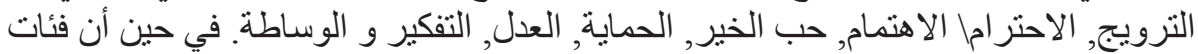

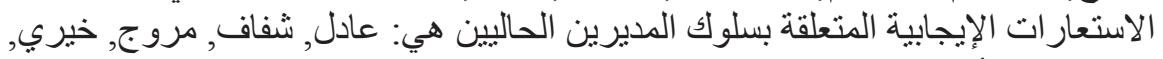

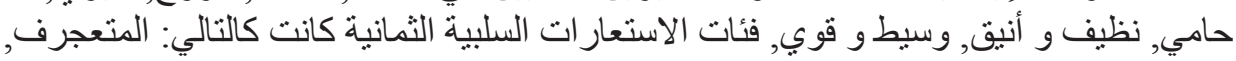

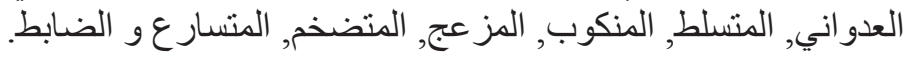
علاوة على ذلك, فإن حوالي 60\% من الاستعار ات التي طور ها المعلمون على مديريهم الحاليين

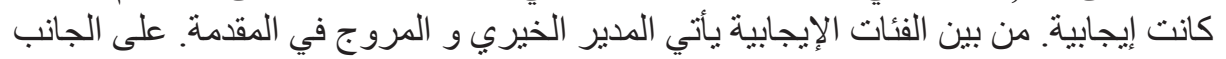

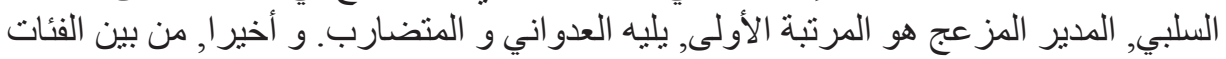
التي حصلت عليها الدر اسة,فئات الحامي, المروج, القوي و الثديد مؤيدة بدارسات سابقة.

\section{الكلمات المفتاحية}

İSMEK, 


\section{Giriş}

Bir uygulama alanı olarak yönetim insanlık tarihi kadar eskidir. Mısır Piramitlerine, Çin Seddi'ne, ya da Süleymaniye Külliyesi'ne baktığımızda bütün açıklığı ile göreceğimiz şey başarılı yönetim uygulamalarıdır. Antik Yunan filozofları, Konfüçyüs ya da Yusuf Has Hacip kendi döneminde yönetim düşüncesini tartışmaya açan düşünürlerdir. Ancakbilimsel bir disiplin olarak yönetimin sadeceyüz elli ylllık bir geçmişi vardır.

Drucker'a (1973) göre planlama, örgütleme, yönlendirme ve denetleme aşamalarından oluşan yönetim süreci insanlığın en büyük buluşlarındandır. Yönetim, sadece işletme yönetimini değil, her tür organizasyonun (kar amacı güden girişimler, kar amacı gütmeyen örgütler, sivil toplum kuruluşları ya da devlet kurumları) etkin ve etkili yönetimi çabasını kapsar. Farklı disiplinlerin yönetim/yönetici tanımlarını yan yana koyarsak göreceğimiz şey, yönetimin bütün uygulama farklılıklarına rağmen evrensel bir kavram olduğudur.

Uygulamalı bir sosyal bilim olan yönetim, sosyal bilimlerin pek çok alanından geniş ölçüde etkilenmiş̧ir. Politika, Ekonomi, Sosyoloji ve Psikoloji sırasıyla yönetime en çok katkı sunan disiplinler olmuşlardır. Bunların yanında Felsefe, Matematik ve hatta Edebiyat'ın yönetim düşüncesinin gelişimine katkısı yadsınmamalıdır (Bursalığlu, 2016).

Yönetim biliminin kuramsal temellerinin eğitime uygulanması ise Eğitim Yönetimi dediğimiz yeni bir disiplinin doğuşunu sağlamıştır. Eğitim Yönetimi, "eğitim sisteminin amacını gerçekleştirebilmek için, eğitim örgütlerinde yer alan insan gücü, sermaye, zaman, malzeme ve yer unsurlarının daha verimli, daha ekonomik ve daha iyi bir biçimde kullanılmasını" ifade eder. Eğitim Yönetimi'ni İşletme Yönetimi'nden ayıran temel özellikleri şu şekilde sıralanabilir (Okutan, 2016):

- Hammaddesi insan olan bu sistemde yapılacak hatalar bir işletmedeki hatalar kadar kolay düzeltilemez.

- Eğitim kurumlarının üzerinde toplumların yarınlarını şekillendiriyor olmaları dolayısıyla büyük bir baskı vardır.

- Eğitim kurumlarında performans değerlendirmesi diğer kurumlara nazaran daha zordur.

Eğitim Yöneticisi olarak aklımıza gelen ilk figür okul müdürüdür. Okulların amaçlarına ulaşmasında ve bunu etkin ve verimli bir biçimde başarmasında müdürün yönetsel yaklaşımının etkisi büyüktür. Örneğin devlet okullarındaki müdürlerin stratejik planlama, örgütleme ve denetleme aşamalarına görece daha az doğrudan etkileri olsa da, operasyonel ve taktik seviyede verdikleri kararlar kurumun başarısını doğrudan etkilemektedir. 
Yönlendirmeişlevi ise bir eğitim kurumu idarecisinin en güçlüyanılmalıdır.Öncelikle öğretmenler olmak üzere paydaşlar arasındaki iletişimi kurma ve güçlendirme; ekibinin bilgi, beceri ve yeterliliklerini geliştirme, çalışanların faaliyetlerini eşgüdümleme gibi faaliyetler bu bağlamda değerlendirilebilir (Başar, 2000; Taymaz, 2019). Kurum kültürünün oluşturulması ve yaşatılmasında yöneticinin yadsınamaz rolü göz önüne alındığında, müdürün kuracağı güven odaklı ilişkilerinönemi daha da ortaya çıkacaktır. Örgün ya da yaygın eğitim versin, kurum müdürü bütün yönetim becerileriyle ama özellikle iletişim becerileriyle hem kurumun performansını hem de öğrenci başarısını doğrudan ve dolaylı etkiler.

Diğer örgütlerde olduğu gibi, eğitim kurumlarında da müdürlerin bilinçli ya da bilinçli olmayan davranış ve söylemleri öğretmenlerinin zihinlerinde farklı algılar oluşturur. $\mathrm{Bu}$ algılarınmetaforlar aracılığıyla ortaya çıkarılması eğitim kurumlarındaki yönetici algımızı, bu algının güçlü ve zayıf yönlerini keşfetmek açısından anlamlıdır(Cerit, 2008).

Metafor, Türk Dil Kurumu ("Metafor,” n.d.) sözlüğünde“mecaz” yani "bir kelimeyi veya kavramı kabul edilenin dışında başka anlamlara gelecek biçimde kullanma" olarak tanımlanır. Bir başka ifadeyle metaforlar, iyi bilinen bir durumun anlamını bilinmeyen bir duruma taşıyarak öğrenme sürecini kolaylaştırırlar (Morgan, 1998). Genelde benzetilen somut bir kavram iken; benzeyen soyut bir kavram olarak karşımıza çıkar.

Eraslan'a (2011) göre metaforlar "bireylerin basit olarak bir kavramı bir başka kavramla açıklamasından daha önemli ve güçlü bir zihinsel üretimdir, çünkü ilgili kavrama dönük sahip olunan derinliği ve deneyimleri ifade ederler". Metaforlar muğlak ve soyut fikirleri somutlaştırmamıza, çok miktarda bilgiyi bir bütün halinde transfer edebilmemize, olgu ve olaylara farklı bakış açıları geliştirmemize olanak sağlarlar (Sackmann, 1989).

Metafor sadece edebi bir sanat olarak düşünülmemeli, dünyayı daha iyi kavramamızı sağlayan bir düşünme biçimi olarak değerlendirilmelidir (Morgan, 1998).Metaforlar sadece günlük yaşamda değil, örgütsel hayatta da sıklıkla kullanılırlar(Balcı, 2008). Metaforların bilimsel düzlemde özellikle de örgüt teorisi kapsamında kullanılması bilimsel dile bir alternatif değil ve fakat onu zenginleştirecek, tamamlayacak bir araç olarak görülmelidir (Tsoukas, 1991). Örneğin; Morgan (1998) örgütleri metaforlar yoluyla tekrar yorumlamış; makine, beyin, kültür, politik sistem gibi farklı benzetmeleri araç olarak kullanmıştır.

Eğitim-öğretim kapsamındaki bütün kavramlarmetaforik araştırmalara konu olmuştur (Çobanoğlu ve Gökalp, 2015). Öğretmen ve öğrencilerin okul algıs1, öğretmenlerin teftiş algısı, öğrencilerin öğretmen algısı ilk akla gelenlerdir. Farklı paydaş gruplarının müdür / idareci ya da yönetici algısı da en ilgi çeken başlıklar arasındadır.

$\mathrm{Bu}$ çalışmada nitel bir araştırma yöntemi olan fenomenoloji kullanılmış, İstanbul Büyükşehir Belediyesi Sanat ve Meslek Eğitimi Kursları'nda (İSMEK) görev yapan öğretmenlerin müdür kavramına ilişkin zihinsel algıları metaforlar aracıllğı ile tespit 
edilmek istenmiştir. Araştırmaya İSMEK bünyesinde farklı branşlarda istihdam edilen 180 öğretmen katılmıştır. İlgili alan yazınında daha çok yaygın eğitim kurumlarında uygulandığı gözlemlenen bu yaklaşım, bir yaygın eğitim kurumu olan İSMEK'te hâkim olan yönetici algısını ve yönetim uygulamalarını değerlendirme firsatı sunmaktadır.

$\mathrm{Bu}$ araştırmanın temel problemi, yaygın eğitim kurumlarında görev yapan öğretmenlerin müdürleriyle ilgilizihinlerinde oluşan olumlu / olumsuz algılardır. Çalışmada aşağıdaki sorulara yanıt aranmıştır:

1. Öğretmenler zihinlerindeki müdür algılarını hangi metaforlaryoluyla açıklamaktadırlar?

2. Müdür kavramı ile ilgili öğretmenler tarafından dile getirilen metaforlar benzerlik ve farklılıklarına göre nasıl sınıflandırılabilir?

3. Müdür kavramına ilişkin listelenen ve sınıflandırılan metaforlar müdürlerin hangi yönleri üzerine yoğunlaşmaktadır?

4. Hızla dönüşen bir çağda eğitim yöneticilerinden beklenen/beklenmeyen tutum ve davranışlar nelerdir?

5. Bu çalışma kapsamında ortaya çıkan müdür algıları, benzer araştırmaların sonuçlarıyla ne derece benzeşmektedir?

\section{Literatür İncelemesi}

Yönetim düşüncesinin gelişimiyle birlikte okul algımız da çok yol kat etmiştir. Öyle ki; günümüzde okullar Sistem Teorisi'nin etkisiyle; öğrenci, materyal, müfredat vb. girdileri alarak eğitim hizmeti sunan ve çıktısı eğitilmiş insan olan açık birer sosyal sistem olarak tanımlanmaktadır (Şişman ve Turan, 2005). Bu açık sistemin işleyişinin birinci derece sorumlusu ise ancak okul müdürüdür.

Deneyimlediğimiz bu sürekli dönüşüm sadece kurumlara değil, kurumları dolduran bireylere bakışımızı da dönüştürmüştür. Bir zamanların bürokratik yöneticileri, önce daha insan odaklı bir çizgiye daha sonra da değişimi/dönüşümü yöneten liderlere evrilmiştir (Lashway, 2003). Öyle ki; okul yöneticilerine dair güncel araştırmalar daha çok müdürlerin liderlik rolleri bağlamında ilerlemektedir. Müdürlerin temel yöneticilik fonksiyonlarının ötesinde çatışmaları doğru yönetmesi, değişim sürecini ateşlemesi ve ekiplerini dönüştürmesi beklenmektedir.

Araştırmalar klasik tanımları zorlayan okul liderliğinin etkili okullara ulaşmada atılması gereken en önemli adım olduğunu vurgulamaktadır (Helvacı ve Aydoğan, 2011).Örneğin 2014-2015 eğitim öğretim yılında Erzincan'da uygulanan bir saha araştırmasında öğretmenlere okul etkinliğini artıran unsurlar sorulmuş ve okul müdürü en önemli oyuncu olarak ön plana çıkmıştır (Uğurlu ve Abdurrezzak, 2016). 
İlgili alan yazınında eğitim kurumu yöneticinin sahip olması gereken özelliklere dair pek çok şey bulmak mümkündür. Scheerens ve Stoel(1988) etkili bir okul yöneticisinin davranışlarını şu şekilde sıralar: Başarıyı vurgular, öğretim stratejileri oluşturur, düzgün bir okul atmosferi hazırlar, sıklıkla öğrenci gelişmelerini izler ve değerlendirir, eğitim ve öğretimi koordine eder ve öğretmenleri destekler. Hoy ve Miskel'e (2012) göre okullar; eleştiren, dönüştüren, vizyon çizen, eğiten, yetkilendiren, özgürlük alanı tanıyan, ahlaki prensiplerden ödün vermeyen, sorumluluklarını bilen, teknolojiyi kullanabilen ve çevresindeki yetenekleri doğru yönetebilen liderlere ihtiyaç duyarlar.

Yedi farklı ülkede (Amerika, İngiltere, Avusturalya, Danimarka, İsveç, Norveç ve Çin) uygulanan bir araştırmanın sonuçları etkin eğitim yöneticilerinin üç ortak noktasına vurgu yapmaktadır: Hedefler koyarak organizasyona yön verme, bireylerin gelişimine katkıda bulunma ve organizasyonu yeniden yapılandırma(Leithwood, 2005). Bu davranışlar etkinlik için yeterli olmamakla beraber olmazsa olmaz kabul edilmektedir.

Etkin örgütlerle ilgili bir diğer önemli özellik etkin iletişim kanallarına sahip olmalarıdır. Yöneticinin her bir paydaş grubu ile kuracağı olumlu ilişki, okulun etkinliğine ve öğrencinin başarısına yansımaktadır. Paydaş grupların arasında en kritik olanı elbette yükseköğrenimini eğitimci olarak tamamlamış bir çalışan kadrosu yani öğretmenlerdir (Çelik, 2003). Bu noktada iletişimin önemini kavramış, etkin iletişim dili kullanan ve bunu destekleyen bir örgüt iklimi oluşturan yöneticiler oldukça başarılı olabilmektedirler.

İletişim, alıcı ve verici arasında kodlanan bir mesajın nakledilmesi, kodun çözülmesi ve geribildirim aşamalarından oluşur. İletişim süreci devam ederken onu olumlu ve olumsuz etkileyecek içsel ve dışsal pek çok faktör olabilir. Çevresel gürültü, alıcı ya da vericinin içinde bulunduğu psikolojik durum vs. bu faktörlerden sadece bir kaçıdır. Bireylerin birbirlerine yönelik algıları da iletişimin etkinliğini belirleyen bir faktördür. $\mathrm{Bu}$ nedenle, yöneticinin birlikte çalıştığı öğretmeninin kendisine ilişkin algısının farkında olması elzemdir.

\begin{abstract}
Algi
"Algılama, bilişsel bir süreç olup, göze kulağa ve diğer alıcılara gelen uyarıcılara anlam verilip yorumlanması şeklinde tanımlanabilir. Algı kişinin iç bilişsel süreçlerinin bir sonucu olarak şekillenir.İnsan doğumdan itibaren yaşamı boyunca duyularını kullanarak çevresinde olup bitenleri anlamak, yorumlamak ve çevresel değişimlere kendini uydurmak için algıyı kullanır.” (Korkmazyürek ve Hazır, 2017)

İnsanlar çevrelerinde olup bitenleri ilgilerinin, düşüncelerinin, yaşlarının, eğitim seviyelerinin, değerlerinin vb. etkisiyle farklı şekillerde algılarlar. Algının zihinsel bir süreç olması,aynı durum karşısında farklı kişilerde farklı algılar oluşmasının da temel nedenidir. Okul örgütlerinde, okul ile bir şekilde ilişkisi bulunan birey sayısı kadar farklı okul, öğretmen, eğitim, öğrenci ve müdüralgısının olması normaldir.
\end{abstract}


Literatürde eğitim kurumu idarecilerine yönelik algıları ortaya çıkarmaya çalışan çalışmaları üç grupta inceleyebiliriz (Tosun, 2018). Birinci grup çalışmalar idarecilerin yaptıkları işe ve sorumluluklarına dair kendi algılarını ortaya çıkarmayı hedeflemektedir. $\mathrm{Bu}$ kapsamda bir idarecinin günlük aktivitelerini inceleyen çalışmaların (Çelikten, 2004) yanı sıra, nelere yönelik sorumluluk hissettiğine dair yaklaşımlarını inceleyen çalışmalar da (Turan, Yıldırım ve Aydoğdu, 2012) vardır. Demirtaş ve Özer (2014) tarafından gerçekleştirilen bir diğer çalışmada ise olgu bilim deseni kullanılarak odak görüşmesi tekniği ile müdürlerin kendileriyle ilgili algılarına ulaşılmaya çalışılmıştır.

İkinci grup çalışmalarda idareci algısı öğrencilerin değerlendirmesine sunulmuştur. Bu kategorideki bir çalışma kapsamında öğrencilerin okul müdürü algıları çizdikleri resimler üzerinden ortaya çıkarılmaya çalışılmıştır. Öğrencilerin “okul müdürü” kavramına ilişkin yapmış oldukları çizimlerin sırasıyla en çok, "olumsuzluk unsuru olma", "sevgi unsuru olma", "sorun çözücü olma”, "aşırı kuralcı olma” ve "değerli bir varlık olma" kategorilerine; en az , "birleştirici/bir araya getirici olma", "aydınlatıcılık", "yetiştiren/şekil veren olma" ve "adaletsiz olma" kategorilerine ait oldukları görülmüştür (Yalçın ve Erginer, 2014). 2014 yılında gerçekleştirilen bir başka çalışmada ise öğrencilerin idareci/yönetici algıları çizdikleri resimler ve kullandıkları metaforlar yardımıyla keşfedilmeye çalışılmıştır. Öğrenci zihninde birlikte yer tutan müdür ve müdür muavinleri daha çok odalarında ve olumlu figürlerle resmedilmiştir. Üretilen metaforlar "iyi bir insan” üst kategorisinde toplanmıştır (Tüzel ve Şahin, 2014). Benzer bir diğer çalışmada ise üç olumlu okul müdürü imajına karşın 12 olumsuz imaj ortaya çıkmıştır. Öğrencilere göre ideal müdür sinirli olmayan ve öğrenci odaklı bir idarecidir (Y1ldırım ve Uğur, 2011).

Öğretmenlerin beraber görev yaptıkları müdürlerine yönelik algılarını keşfetmeye çalışan araştırmalar ise üçüncü bir grup olarak sınıflandırılabilir. Türkçe alan yazınında öğretmenlerin yöneticilerini nasıl algıladıklarını keşfetmeye çalışan çok fazla çalışmaya rastlanmamıştır. Uğurlu ve Abdurrezzak (2016) dokuz açık uçlu soru üzerinden öğretmenlerin etkili okul ve okul liderliğine dair algılarını içerik analizi yaparak yorumlamıştır. Müdürlerini lider olarak benimseyen öğretmenlerin müdürlerinden üç temel beklentileri vardır: destek, işbirliği ve empati. Bir başka çalışmada ise öğretmenlerin okul müdürü kavramına ilişkin zihinsel algıları metaforlar aracılığg ile tespit edilmek istenmiştir. Erzincan ilinde görev yapan 106 öğretmen, idarecilerini 24 farklı metafor kullanarak tasvir etmiştir. En sık kullanılan metaforlar; komutan, asker, bilgisayar, kalem,ve yönetici olmuştur (Akan, Yalçın ve Yıldırım, 2014). Siirt il merkezindeki 16 farklı ortaokulda görev yapan 210 öğretmen üzerinde uygulanan bir başka araştırmada 96 metafor elde edilmiştir. Bu metaforların çoğunluğunun olumlu olduğu görülmüştür. "Yol Gösterici ve Lider Biri Olarak" müdür en güçlü, "Bilginin Depolayıcısı Olarak Okul Müdürü” en zayıf kategoridir (Korkmaz ve Çevik, 2018).

Tüzel ve Kalyon (2012) tarafından gerçekleştirilen çalışmanın amacı ise sınıf öğretmeni adaylarının okul yöneticilerine ilişkin algılarını metaforlar aracılığı ile ortaya çıkarmak olmuştur. Ankara'da bir devlet üniversitesinde farklı sınıflarda eğitimlerine devam eden 190 sınıf öğretmeni adayına müdür ve müdür yardımcılarını metaforlar 
yardımıyla tasvir etmeleri istenmiştir. "Görev Algısı" ve "Olumsuz İmaj Algısı" ana temaları altında pek çok alt tema üretilmiştir. Bu alt temaların pek çoğunun olumsuz öğelerden oluşması dikkat çekicidir. Benzer bir çalışma Ankara ilinde iki farklı üniversitenin Eğitim Fakülteleri’nde öğrenim gören öğretmen adaylarına uygulanmıştır. Öğretmen adaylarının okula ilişkin algıları olumlu iken;okul yöneticisi ve sisteme yönelik algılarının olumsuz olduğu görülmüştür. Ancak, sistemsel sorunlar ortadan kaldırıldığında yönetici algısının da düzelebileceği öngörülmüştür (Örücü, 2014). Recep Tayyip Erdoğan Üniversitesi Eğitim Fakültesi son sınıf öğrencileri okul müdürleri için sırasıyla en çok "Baba", "Aslan Anne", "Diktatör", ve "Çoban" metaforlarını kullanmışlardır. Aday öğretmenlerin müdür algılarının \%90 oranında olumlu olduğu görülmüştür (Çobanoğlu ve Gökalp, 2015).

\section{Yöntem}

$\mathrm{Bu}$ araştırmada İstanbul Büyükşehir Belediyesi Sanat ve Meslek Eğitimi Kursları'nda görev yapan öğretmenlerin müdür/yönetici kavramına ilişkin zihinsel algıları fenomenoloji (olgubilim) kullanılarak tespit edilmeye çalışılmıştır. Çalışmanın bu bölümü, araştırma deseni, çalışma grubu, verilerin toplanması ve çözümlenmesi süreçleri hakkında detaylı bilgi vermeyi amaçlamaktadır.

\section{Araștırma Deseni}

Fenomen (olgu), varolan, somut, algılanabilir ve günlük hayatlarımızda karşımıza çıkan olay ve nesnelerdir. Fenomenoloji ise fenomeni direk ve aracısız olarak anlama çabasıdır. $\mathrm{Bu}$ araştırma deseni katılımcıların farklı olgulara ilişkin algılarını ortaya çıkarmayı, olgunun katılımcı zihnindeki anlamını/karşılığını keşfetmeyi hedefler (Sığrı, 2018).

Katılımcı fenomeni bizzat deneyimlemiş bir kişi olmalıdır. Çünkü fenomenolojik araştırma iki temel soruya odaklanır: Katılımcının olguya ilişkin kişisel deneyimleri nelerdir? Bu deneyim nasıl bir bağlamda ortaya çıkmıştır? Kısaca ifade etmek gerekirse; katılımcıların birbirinden bağımsız deneyimlerindeki benzerlikler ilgili fenomeni daha iyi anlamamıza yardımcı olur (Creswell, 2017)

Araştırmada bir nitel araştırma yöntemi olan fenomenoloji kullanılmış, İSMEK öğretmenlerinin müdürkavramına ilişkin algılarınınmetaforlar aracılığıyla keşfedilmesi hedeflenmiştir. Kompleks fenomenleri daha yalın ve anlaşılabilir bir biçimde ortaya koyan metaforlar son yıllarda sosyal bilimler araştırmalarında oldukça rağbet görmektedir. İncelenen fenomene dair güçlü bir temsil, bütüncül bir resim ve zengin bir veri kaynağı sunar. "X . ..........benzer, çünkü...................." cümlesiyle katılımcıların zihinlerindekiX algısı ve bu algının gerekçesi elde edilmiş olur. "Gibi" kelimesi metafor konusu ile metafor kaynağı arasındaki benzerliği net bir şekilde çağrıştırırken, "çünkü” kelimesi benzetmenin sebebine odaklanır. (Şimşek ve Yı1dırım, 2018). 


\section{Çalışma Grubu}

Araştırmanın katılımcıları 2018-2019 eğitim-öğretim yılında İstanbul Büyükşehir Belediyesi Sanat ve Mesleki Eğitim Kurumları'nda (İSMEK) farklı branşlarda görev alan 180 öğretmenden oluşmaktadır. Araştırmaya katılan öğretmenlerin \%45'i erkek, \%55'i kadındir.

\section{Veri Toplama Aracı}

Araştırmaya katılan öğretmenlere üzerinde "okul müdürü..................gibidir/ benzemektedir, çünkü....................” cümlesi yer alan formlar dağıtılmış ve ifadeyitek bir metafor üzerinde yoğunlaşarak tamamlamalarıistenmiştir.

\section{Verilerin Analizi}

Araştırma verilerinin analizinde takip edilen aşamalar şu şekildedir:

1. Kodlama ve ayıklama,

2. Kategori oluşturma,

3. Geçerlik ve güvenirlik,

4. Nicel veri analizi

5. Yorumlama

Formlar önce kabaca gözden geçirilmiş, her bir metafor ifadesi dikkatle incelenmiş ve metaforik bir ifade olarak değerlendirilemeyecek olan formlar elenmiştir. Ayıklama sonrasında 119metafor elde edilmiştir. Kategori oluşturma işlemleri için üretilen metaforlar konusu, kaynağı, konu-kaynak ilişkisi göz önünde bulundurularak içerik analizi ve betimsel analiz yoluyla incelenmiştir. $\mathrm{Bu}$ incelemeler neticesinde benzer veriler belirli kavram ve temalar çerçevesinde bir araya getirilmiş (Şimşek ve Yıldırım, 2018); böylece üç ana ve 21 alt kategoriye ulaşılmıştır. $\mathrm{Bu}$ kategoriler çalışmanın çekirdeğini oluşturmaktadır.

Geçerlilik ve güvenirlilik kontrolü için çeşitli metotlara başvurulmuştur. Örneğin; iç geçerlilik uzman görüşüne başvurularak sağlanmıştır. Ayrıca katılımcıların ürettikleri metaforlar metin içinde paylaşılarak dış geçerliliğin sağlanması hedeflenmiştir. Nitel araştırmalarda doğrudan katılımcı görüşlerine yer vermek kabul görmüş bir geçerlilik sağlama metodudur.

Kâğıt üzerinde toplanan metaforlar Microsoft Excel programına taşınmış, bilgisayar ortamında analiz edilerek sıklık değerleri elde edilmiştir. Öte yandan, metaforlar ve oluşturulan ana ve alt kategoriler tablolaştırılarak anlaşılır bir biçimde raporlanmıştır. En son aşamada ise elde edilen bulgular yorumlanmıştır.

\section{Bulgular}


Yapılan analizler kurum müdürünün öğretmene davranışına ilişkin metaforların iki ana kategoride toplandığını göstermiştir:

1. Mevcut müdür davranışı algısını yansıtan metaforlar

a. Mevcut müdür algısını yansitan pozitif metaforlar

i. Adaletli / Şeffaf

ii. Geliştiren

iii. İyi Davranan / İyi Hissettiren

iv. Koruyan

v. Temiz / Düzenli

vi. Arac1

vii. Muktedir

b. Mevcut müdür algısını yansıtan negatif metaforlar

i. Kibirli

ii. Agresif

i. Buyurgan

ii. Seviyesiz

iii. Rahatsiz eden

iv. Değişken

V. Aceleci

vi. Cezalandiran

2. Beklenen / olması gereken müdür davranışı algısına ilişkin metaforlar
a. Geliştiren
b. Değen Veren / Özen Gösteren
c. İyi Davranan / İyi Hissettiren
d. Koruyan
e. Adaletli
f. Sert
g. Arac1 


\section{Mevcut Müdür Davranışı Algısını Yansıtan Metaforlar}

Öğretmenlerin mevcut müdür davranışına ilişkin algıları 2 alt kategoride toplanmıştır. Mevcut müdür algısını yansıtan pozitif metaforlara ait yedi alt kategori Tablo 1'de, negatif metaforlara ait 7 alt kategori ise Tablo 2'de detaylarıyla gösterilmiştir.

Tablo 1

Mevcut Müdür Davranışına İlişkin Pozitif Metaforlar

\begin{tabular}{|c|c|c|}
\hline Alt Kategoriler & & \\
\hline $\begin{array}{l}\text { Adaletli / Şeffaf } \\
\text { Hâkim Tokmağı (1),Yol (1),Hâkim (1),Su (1) }\end{array}$ & 4 & 4 \\
\hline $\begin{array}{l}\text { Geliştiren } \\
\text { Usta-çırak ilişkisi (1), Ağaç sulama (1), Projeksiyon (1), } \\
\text { Şelale (1), Otobüs Şoförü (1), Mum (1), Türk bayrağ (1), Kitap } \\
\text { (1), Ütü (1), Antrenör (1), Pusula (1), Profesör (1), Yol (1) }\end{array}$ & 13 & 13 \\
\hline $\begin{array}{l}\text { İyi Davranan / İyi Hissettiren } \\
\text { Baklava (2), Deniz (1), Çizgi film (1), Yıldız (1), Çikolata } \\
\text { (1), Bahçıvan (1), Klima (1), Mücevher kutusu (1), İnci (1), } \\
\text { Şiir (1), Bayram şekeri (1), Spor (1), Kar tanesi (1), Kelebek } \\
\text { (1), Pamuk şeker (1), Uğur böceği (1), Buz torbası (1), Plates } \\
\text { (1), Baba şefkati (1), Güneş (1), Köprü (1) }\end{array}$ & 21 & 22 \\
\hline $\begin{array}{l}\text { Koruyan } \\
\text { Güvercin Kanadı (1), Komşu (1), Baba (1), Perde (1), } \\
\text { Arabulucu (1), Anne (1), Mandal (1), Mizrak (1) }\end{array}$ & 8 & 8 \\
\hline $\begin{array}{l}\text { Temiz / Düzenli } \\
\text { Mavi renk (1), Bilgisayar (1) }\end{array}$ & 2 & 2 \\
\hline $\begin{array}{l}\text { Araci } \\
\text { Televizyon (1) }\end{array}$ & 1 & 1 \\
\hline $\begin{array}{l}\text { Muktedir } \\
\text { Teknik direktör (2) }\end{array}$ & 1 & 2 \\
\hline TOPLAM & 50 & 52 \\
\hline
\end{tabular}

Mevcut müdür / idareci davranışına ilişkin pozitif yedi metafor kategorisi şu şekilde sıralanmaktadır: Adaletli / Şeffaf, Geliştiren, İyi Davranan / İyi Hissettiren, Koruyan, Temiz / Düzenli, Aracı, Muktedir. 
Adaletli alt kategorisi incelendiğinde, dört farklı katılımcının dört farklı metafor ürettikleri görülmüştür. Bu kategoriye ait metaforlara birkaç örnek vermemiz gerekirse:

Kurum müdürünün öğretmene davranışı hâkim tokmağına benzer, çünkü her zaman adaletlidir.

Kurum müdürünün öğretmene davranışı suya benzer, çünkü şeffaftır.

Kurum müdürünün öğretmene davranışı yola benzer, çünkü istikrarlı şekilde herkese aynı davranır.

Örneklerden de anlaşılacağı üzere öğretmenler idarecilerinin bütün çalışanlara eşit mesafede durduklarını, adaletli davrandıklarını vurgulamışlardır.

Geliştiren alt kategorisi incelendiğinde, 13 farklı katılımcının 13 farklı metafor ürettikleri görülmüştür. Bu kategoriye ait metaforlardan bazıları şunlardır:

Kurum müdürünün öğretmene davranışı usta çırak ilişkisindeki ustaya benzer.

Çünkü usta, bildiği bütün şeyleri çırağına öğreterek, onun kendisinden de iyi bir usta olmasını amaçlar.

Kurum müdürünün öğretmene davranışı ăgacı sulamaya benzer; çünkü öğretmenlerini birer meyve gibi yetiştirir.

Kurum müdürünün öğretmene davranışı pusulaya benzer, çünkü bizleri pozitif yönde etkiler.

Kurum müdürünün öğretmene davranışı muma benzer, çünkü bizleri aydınlatır.

Kurum müdürünün ögretmene davranışı kitaba benzer, çünkü tecrübesi vardır.

Örnekler öğretmenlerin müdürlerini onları geliştiren, yönlendiren, daha iyi bir noktaya taşımaya çalışan yöneticiler olarak algıladıklarını göstermektedir. Yönetici sadece işlerin zamanında ve doğru bir biçimde tamamlanmasını sağlayan kişi değildir. Yönetici işi tamamlarken ekibini de ileriye doğru hareket ettiren kişidir.

İyi Davranan / İyi Hissettiren alt kategorisi incelendiğinde, 22 farklı katılımcının 21 farklı metafor ürettikleri görülmüştür. Bu kategoriye ait metaforlardan bazıları şunlardır:

Kurum müdürünün öğretmene davranışı baklavaya benzer, çünkü tatlı dillidir.

Kurum müdürünün öğretmene davranışı mücevher kutusuna benzer, çünkü ögretmenlerine değerli olduklarını hissettirir.

Kurum müdürünün öğretmene davranışı denize benzer; çünkü huzur veren bir yöneticidir.

Kurum müdürünün öğretmene davranışı klimaya benzer, çünkü müdürümüz öğretmenlerini gerektiğinde rahatlatır gerektiğinde sevgisiyle ısıtır. 
Örnekler göstermektedir ki, 22 farklı katılımcı mevcut müdürlerinin davranışlarını olumlu algılamakta ve kendilerini onların yanında iyi hissetmektedirler. Müdürleri onlara değer veren, onları rahatlatan davranışlar sergilemektedir. Müdürler, sadece davranışlarıyla değil sözleriyle de pozitif bir algı oluşturmayı başarmışlardır.

Koruyan alt kategorisi incelendiğinde, sekiz farklı katılımcı tarafindan üretilen sekiz farklı metaforla karşılaşmaktayız. Bu kategoriye ait metaforlara birkaç örnek vermemiz gerekirse:

Kurum müdürünün ögrretmene davranışı güvercinin kanatlarına benzer, çalışanını zaman zaman korur.

Kurum müdürünün öğretmene davranışı mandala benzer, çünkü bizleri sıkıca sahiplenir.

Kurum müdürünün öğretmene davranışı mızrağa benzer, çünkü çalışanlarını korur.

Katılımcılara göre müdürleri her zaman yanlarında durmakta, onları zor durumlarda koruyup kollamakta, üstlerine ve dışarıya karşı savunmaktadır. Bu davranışlar öğretmenlerde kurum müdürlerine karşı olumlu bir algı ortaya çıkarmıştır.

Temiz/ Düzenli alt kategorisi incelendiğinde, iki farklı katılımcının yöneticilerine yönelik bu yöndeki algılarını iki farklı metaforla açıkladıklarını görmekteyiz. Bu kategoriye ait metaforlar şunlardır:

Kurum müdürünün ögrretmene davranışı mavi renge benzer, çünkü müdürüm hep temiz ve tertiplidir.

Kurum müdürünün öğretmene davranışı bilgisayara benzer, çünkü düzenlidir.

Yukarıdaki metaforlar 1şığında söyleyebiliriz ki; kurum müdürünün öğretmenlerine yönelik davranışlarında öne çıkan boyut, yöneticinin düzenli olması, düzenli çalışması olmuştur. Çalışanların zihinlerinde bu yönde bir algı ortaya çıkmıştır.

Muktediralt kategorisi incelendiğinde, iki farklı katılımcının yöneticilerine dönük bu yöndeki algılarını aynı metaforla açıkladıklarını görmekteyiz. Bu kategoriye ait metaforlar şunlardır:

Kurum müdürünün öğretmene davranışı teknik direktörün takımı idare edişine benzer, çünkü aldığı kararlar, verdiği geri dönüşler, oyuncularla olan iliş̧kisi takımın kaderini belirler.

Kurum müdürünün öğretmene davranışı teknik direktöre benzer, çünkü kurumu şampiyon da yapabilir küme de düşürebilir.

Kurumların başarı ya da başarısızlıklarında pek çok faktör önemli rol oynar. Kurum içerisinde ve dışarısındaki değişkenler kurumu ileriye taşıyabileceği gibi, zor durumda da bırakabilir. Yöneticilerin fonksiyonu ise oldukça tartışmalıdır. Öyle görünüyor ki katılımcılardan bir kısmı için müdürleri muktedirdir. Yani başarının ya da başarısızlığın esas sorumlusu müdürlerdir. 
Katılımcılardan sadece biri tarafından dile getirilen bir diğer metafor ise yöneticilerin iletişim fonksiyonuna ilişkindir.

Kurum müdürünün öğretmene davranışı televizyona benzer, çünkü bize genel merkezden son dakika mesajlarl iletir.

Mevcut müdür / idareci davranışına ilişkin negatif sekizmetafor kategorisi Tablo 2'de görüldüğü gibi şu şekilde sıralanmaktadır: Kibirli, Agresif, Buyurgan, Seviyesiz, Rahatsız Eden, Değişken, Aceleci veCezalandıran.

Tablo 2:

Mevcut Müdür Davranışına İlişkin Negatif Metaforlar

\begin{tabular}{|c|c|c|}
\hline Alt Kategoriler & & \\
\hline $\begin{array}{l}\text { Kibirli } \\
\text { Patron-işçi ilişkisi (1), Eskimiş kumaş (1), Cips poşeti (1), } \\
\text { Boks çuvalı (1) }\end{array}$ & 4 & 4 \\
\hline $\begin{array}{l}\text { Agresif } \\
\text { Çarpışan araba (1), Bıçak (1), Haşlama yemek (1), Trafo } \\
\text { (1), Hindistan Cevizi (1), Tsunami (1), Şimşek (1) }\end{array}$ & 7 & 7 \\
\hline $\begin{array}{l}\text { Buyurgan } \\
\text { Asker (1), Balık ağı (1), Kaf dağı (1), Mutfak robotu (1), } \\
\text { Robot (1) }\end{array}$ & 5 & 5 \\
\hline $\begin{array}{l}\text { Seviyesiz } \\
\text { Armut (1) }\end{array}$ & 1 & 1 \\
\hline $\begin{array}{l}\text { Rahatsız Eden } \\
\text { İğne (1), Etiket (1), Gözyaşı (1), Ekmek kuyruğu (1), } \\
\text { Kırılmayan şeker (1), Sivrisinek (1), Un çuvalı (1), Acı biber } \\
\text { (1), Toka (1) }\end{array}$ & 9 & 9 \\
\hline $\begin{array}{l}\text { Değişken } \\
\text { Oyuncu (1), Bukalemun (1), Politikacı (1), Borsa (1), } \\
\text { Meteoroloji (1), Stadyum Seyircisi (1), Plates topu (1) }\end{array}$ & 7 & 7 \\
\hline $\begin{array}{l}\text { Aceleci } \\
\text { Araba tekeri (1), Yüksek hizlı tren (1), Saat (1) }\end{array}$ & 3 & 3 \\
\hline $\begin{array}{l}\text { Cezalandıran } \\
\text { Silah (1), Hukuk kuralları (1) }\end{array}$ & 2 & 2 \\
\hline TOPLAM & 38 & 38 \\
\hline
\end{tabular}


Kibirli alt kategorisi incelendiğinde, katılımc1ların dört metafor ürettiği ve üretilen metaforların tekrarlanma sıklığının bir olduğu görülmektedir. Bu kategoriye ait metaforlardan bazıları şu şekilde örneklendirilebilir:

Kurum müdürünün öğretmene davranışı patronun işçisine davranışına benzer. Çünkü kendini ondan üstün görür.

Kurum müdürünün öğretmene davranışı eskimiş kumaşa benzer; çünkü onu değersiz görür.

Örneklerden hareketle denilebilir ki; müdürlerin kimi davranışlarından ötürü öğretmenler kendilerini oldukça değersiz hissetmekte ve bu tutumları olumsuz algılamaktadırlar. Bazen yapılan işin küçümsenmesi bazen de as üst ilişkisindeki dengesizlikler, öğretmenlerin zihinlerinde olumsuz algılara sebebiyet vermektedir.

Agresif alt kategorisi incelendiğinde, katılımcıların 11 metafor ürettiği ve üretilen metaforların tekrarlanma sıklığının bir olduğu görülmektedir. Bu kategoriye ait metaforlardan bazıları şu şekilde örneklendirilebilir:

Kurum müdürünün öğretmene davranışı çarpışan arabaya benzer,çünkü kime ne zaman firça atacă̆ belli olmaz.

Kurum müdürünün öğretmene davranışı trafoya benzer; hiçbir şikayette eleştiride bulunmayacaksin,bulunursan yanarsin.

Kurum müdürünün öğretmene davranışı tsunamiye benzer;çünkü bazen öğretmenlere yükselip söylemiyle bizleri dağıtabiliyor.

Kurum müdürünün öğretmene davranışı kızartma tavasına benzer;çünkü öğretmeni gerektiğinde sözleriyle yaklyor (üzüyor).

Öğretmenlerin zihinlerindeki kurum müdürüne ait negatif imajlardan bir tanesi de müdürlerin agresif olmalarıdır. Ne zaman sinirleneceği belli olmayan, eleştiri kabuletmeyen, öfkesini kontrol edemeyen yöneticilere kiplerinde olumsuz bir alg1 oluşturmuşlardır. Bu olumsuz algı hem kurum kültürünü, hem de performansı olumsuz etkiler.

Buyurgan alt kategorisi incelendiğinde, beş farklı katılımcının yöneticilerine yönelik bu yöndeki algılarını beş farklı metaforla açıkladıklarını görmekteyiz. Bu kategoriye ait metaforlardan birkaçı şunlardır:

Kurum müdürünün öğretmene davranışı askere benzer, çünkü hep emir veriyor.

Kurum müdürünün öğretmene davranışı balık ăğına benzer, çünkü öğretmeni ele geçirip istediği gibi davranmasını ister. 
Yukarıdaki metaforlar 1şığında söyleyebiliriz ki; öğretmenler müdürlerinin buyurgan tutumlarından rahatsız olmaktadırlar. Sürekli emirler veren ve emirlerine sorgusuz sualsiz itaat bekleyen müdürler, çalışanlarının zihinlerinde olumsuz bir yönetici algısı yaratmaktadir.

Rahatsız Eden / Inciten alt kategorisi incelendiğinde, katılımc1ların dokuz metafor ürettiği ve üretilen metaforların tekrarlanma sıklığının bir olduğu görülmektedir. $\mathrm{Bu}$ kategoriye ait metaforlardan bazıları şu şekilde örneklendirilebilir:

Kurum müdürünün öğretmene davranışı çamaşırlardaki etikete benzer, çünkü sözleri ve davranışları ile sürekli rahatsız ediyor.

Kurum müdürünün öğretmene davranışı sivrisineğe benzer, çünkü hep söylenir, hep talep eder, takdir etmez.

Kurum müdürünün öğretmene davranışı iğneye benzer, çünkü söylemleriyle bizleri iğneler.

Müdürün söz ve davranışlarıyla öğretmenlerini iğnelemesi, ağır sorumluluklar vermesi ve hiç takdir etmemesi öğretmenlerin zihinlerinde yöneticilerine ilişkin olumsuz bir alg1 yaratmaktadır. Diğer alt kategorilerden farklı olarak burada öğretmenlerin duygusal incinmişlikleri ön plandadır.

Katılımcılardan sadece biri tarafından dile getirilen bir diğer metafor ise yöneticilerin seviyesiz tutum ve davranışlarına ilişkindir:

Kurum müdürünün ögrretmene davranışı armuta benzer, çünkü çok sulu davranışlarda bulunuyor.

Değişken alt kategorisi incelendiğinde, yedi farklı katılımcının bu yöndeki algılarını yedi farklı metaforla açıkladıkları görülmektedir. Bu kategoriye ait metaforlardan birkaçı şunlardır:

Kurum müdürünün ögretmene davranışı bukalemuna benzer; çünkü yönetici her türlü taleple gelen öğretmeninin isteğini kabul eder. Her renge bürünen bukalemun gibi davranır.

Kurum müdürünün öğretmene davranışı borsaya benzer; çünkü inişli çıkışlı davranır.

Kurum müdürünün öğretmene davranışl plates topuna benzer; çünkü her duruma ve davranışa göre şekil değiştirebiliyor.

Siralanan metaforlarda gördüğümüz gibi kurum yöneticisinin istikrarlı olmayan davranışları öğretmenler tarafından borsa, tsunami, pilates topu, politikacı ve meterolojiye benzetilmiştir. Eğitim kurumu içerisinde bir müdürün bu tarz dengesiz tutumları̈ğretmenler tarafından negatif bir özellik olarak algılanmaktadır. 
Aceleci alt kategorisi incelendiğinde, katılımcıların üç metafor ürettiği ve üretilen metaforların tekrarlanma sıklığının bir olduğu görülmektedir. Bu kategoriye ait metaforlardan bazıları şu şekilde örneklendirilebilir:

Kurum müdürünün öğretmene davranışı yüksek hızlı trene benzer,çünkü verilen görevi hızlıca yapmamızı bekler.

Kurum müdürünün öğretmene davranışı saate benzer, çünkü hep dakik olmalıyı asla geç kalmamalıyız, ama biz insanız.

Öğretmenler yöneticilerinin işlerin zamanında tamamlanması hususunda esnek olmadıklarından, hatta oldukça katı olduklarından şikâyet etmektedirler. Bu durum onların zihinlerinde yöneticileri ile ilgili olumsuz bir algı oluşturmaktadır.

Cezalandıran alt kategorisi incelendiğinde, iki katılımcının iki farklı metafor ürettiği görülmektedir. Bu kategoriye ait metaforlar şunlardır:

Kurum müdürünün öğretmene davranışı silaha benzer. Çünkü kuralları uygulamazsan vurulursun, yani seni işten atarlar.

Kurum müdürünün öğretmene davranışı hukuk kurallarına benzer, çünkü yaptırım gücü vardır.

Yönetici yetkisini kullanarak çalışanlarını cezalandırabilir. Bu cezalandırma yetkisi kötüye kullanıldığında ise, öğretmenlerin zihinlerindeki olumsuz müdür algısına yeni bir boyut eklemiş oluruz.

Tablo 3, yukarıda detaylı bir biçimde açıklanan öğretmenlerin mevcut müdür algılarına ilişkin yüzdelik tablosudur. Araştırmamız kapsamında ortaya çıkan mevcut müdür algısına ilişkin metaforların yaklaşık olarak \% 60'ı pozitif, geri kalanı ise negatif içeriklidir. Pozitif metaforların arasında iyi davranan / iyi hissettiren ve geliştiren lider davranışı öne çıkmaktadır. Negatif metaforlara baktığımızda ise, birinci sırayı rahatsız eden lider davranışları almıştır. Onu agresifve değişken müdür davranışları izlemektedir. 
Tablo 3:

Öğretmenlerin Mevcut Müdür Algılarına Genel Bir Bakış

\begin{tabular}{|c|c|c|c|c|}
\hline Ana Kategoriler & $\%$ & Alt Kategoriler & $\mathrm{f}$ & $\%$ \\
\hline \multirow{7}{*}{$\begin{array}{l}\text { Mevcut } \\
\text { Metaforlar }\end{array}$} & \multirow{7}{*}{$\begin{array}{c}\% \\
57,78\end{array}$} & Adaletli / Şeffaf & 4 & 4.44 \\
\hline & & Geliştiren & 13 & 14.44 \\
\hline & & İyi Davranan / İyi Hissettiren & 22 & 24.44 \\
\hline & & Koruyan & 8 & 8.89 \\
\hline & & Temiz / Düzenli & 2 & 2.22 \\
\hline & & Araci & 1 & 1.11 \\
\hline & & Muktedir & 2 & 2.22 \\
\hline \multirow{8}{*}{$\begin{array}{l}\text { Mevcut Negatif } \\
\text { Metaforlar }\end{array}$} & \multirow{8}{*}{$\begin{array}{r}\% \\
42.22\end{array}$} & Kibirli & 4 & 4.44 \\
\hline & & Agresif & 7 & 7.78 \\
\hline & & Buyurgan & 5 & 5.56 \\
\hline & & Seviyesiz & 1 & 1.11 \\
\hline & & Rahatsiz Eden & 9 & 10.00 \\
\hline & & Değişken & 7 & 7.78 \\
\hline & & Aceleci & 3 & 3.33 \\
\hline & & Cezalandıran & 2 & 2.22 \\
\hline TOPLAM & & & 90 & \\
\hline
\end{tabular}

\section{Beklenen / Olması Gereken Müdür Davranışı Algısına İlişkin Metaforlar}

Beklenen / olması gereken müdür davranışı algısına ilişkin yedi alt kategori Tablo 3’te görüldüğü gibi şu şekilde sıralanmaktadır: Geliştiren, Değer Veren / Özen Gösteren, İyi Davranan / İyi Hissettiren, Koruyan, Adaletli, Sert, Arac1. 
Tablo 4:

Olması Gereken / Beklenen Müdür / İdareci Davranışları ve Dağılımları

\begin{tabular}{|l|c|c|c|}
\hline Alt Kategoriler & & $\begin{array}{r}\text { Kişi } \\
\text { Sayıs }\end{array}$ & $\%$ \\
\hline Geliştiren & 4 & 4 & $\mathbf{1 3 . 7 9}$ \\
Uçak (1), Sürahi (1), Anne (1), El Feneri (1) & 2 & 2 & $\mathbf{6 . 9 0}$ \\
\hline $\begin{array}{l}\text { Değer Veren / Özen Gösteren } \\
\text { Altın kolye (1), Yemek (1) }\end{array}$ & 7 & 9 & $\mathbf{3 1 . 0 3}$ \\
\hline $\begin{array}{l}\text { İyi Davranan / İyi Hissettiren } \\
\text { Çiçek (2), Bulut (2), Neskafe (1), Uçak (1), Pamuk } \\
\text { (1), Havlu (1), Güneş (1) }\end{array}$ & 7 & 6 & $\mathbf{2 0 . 6 9}$ \\
\hline $\begin{array}{l}\text { Koruyan } \\
\text { Avukat (1), Orman (1), Fermuar (1), Kalkan (1), }\end{array}$ & 6 & 29 & $\mathbf{1 0 0}$ \\
\hline Şemsiye (1), Kaptan (1)
\end{tabular}

Geliştiren alt kategorisi incelendiğinde, katılımcıların dört metafor ürettiği ve üretilen metaforların tekrarlanma sıklığının bir olduğu görülmektedir. Bu kategoriye ait metaforlardan bazıları şu şekilde örneklendirilebilir:Kurummüdürününöğretmenedavra nışıuçağabenzer,çünküöğretmeninieğitimselanlamdayükseğeçıkarmalı,tecrübesiyleken dinikeşfedipyükselmesinisağlamalıdır.

Kurum müdürünün öğretmene davranışı el fenerine benzer, çünkü öğretmenlere tecrübesiyle yol göstermelidir.

Örneklerden hareketle denilebilir ki; öğretmenler müdürlerinden tecrübeleri ile onlara yol göstermelerini, kişisel gelişimlerine ve kariyerlerine destek olmalarını beklemektedirler. Öğretmenlerin zihinlerinde yol gösteren, destekleyen bir ideal müdür algisı vardır.

Değer Veren alt kategorisi incelendiğinde, iki farklı katılımcı tarafından üretilen iki farklı metafor karşımıza çıkmaktadır. Bu kategoriye ait metaforlar şu şekilde örneklendirilebilir: 
Kurum müdürünün öğretmene davranışı altın kolyeye benzer,çünkü hocasını değerli hissettirmeli ki işte verimliliğimiz artsın.

Kurum müdürünün ögretmene davranışl yemek yapmaya benzer,çünkü yemeğe ne kadar özenir ve malzemelerin tazeliğine, kalitesine ne kadar dikkat ederseniz yemek o kadar lezzetli olur.

Öğretmenlerin zihinlerindeki ideal müdür algısına ilişkin bir diğer özellik ise, müdürün ekibine değer vermesi, onların üzerine titremesidir. Öğretmenlerin gözünde as-üst ilişkisi altın değerindedir. Ortaya güzel işler çıkarmak isteyen bir müdür ancak öğretmenlerine hak ettikleri değeri verirse başarılı olabilecektir.

İyi Davranan / İyi Hissettiren alt kategorisi incelendiğinde, dokuz katılımcının yedi farklı metafor ürettiği ve üretilen metaforların tekrarlanma sıklığının bir ve iki olduğu görülmektedir. Bu kategoriye ait örnek metaforlar şunlardır:

Kurum müdürünün öğretmene davranışı saksıdaki çiçeğe benzer. Çünkü bir çiçeğe iyi davranıldı̆̆ gibi insana da iyi davranılması gerekmektedir.

Kurum müdürünün ögrretmene davranışı buluta benzer, çünkü bizi rahatlatmalıdır.

Kurum müdürünün öğretmene davranışı pamuğa benzer, çünkü öğretmenlere pamuk gibi yumuşak ve sıcak davranmalıdır.

Kurum müdürünün öğretmene davranışı havluya benzemelidir, çünkü hem öğretmeni sıkıca kuşatmalı hem de yumuşak olmalıdır.

Örneklerde de gördüğümüz üzere öğretmenler müdürlerini sadece bir yönetici, kurumlarını da para kazandıkları bir yer olarak algılamamaktadırlar. İdareciler çalışanlarına şefkat, merhamet ve anlayış göstermeli, kurumlarını bir aile sıcaklığında yönetmelidirler. Huzurlu bir ortamda çalışan öğretmenler şüphe yok ki yüksek motivasyon ve yüksek performans göstereceklerdir.

Koruyan alt kategorisi incelendiğinde, altı farklı katılımcı tarafından üretilen altı farklı metafor karşımıza çıkmaktadır. Bu kategoriye ait metaforlar şu şekilde örneklendirilebilir:

Kurum müdürünün öğretmene davranışı şemsiyeye benzer, gerektiğinde hocasını şikâyetlerden, yaptırımlardan korumalıdır.

Kurum müdürünün öğretmene davranışı fermuara benzer, çünkü özel konular iki kişi arasında kalmalıdır.

Kurum müdürünün öğretmene davranışı avukata benzer, çünkü gerektiğinde ögretmenini savunmalıdır.

$\mathrm{Bu}$ alt kategorideki metaforlaröğretmenin gözünde kurum müdürünün koruyucu fonksiyonunu ortaya çıkarmıştır. Müdür, öğretmenlerini üst yönetimden, şikâyetlerden ve yaptırımlardan bir avukat ya da şemsiye gibi korumalıdır. 
Adaletli alt kategorisi incelendiğinde, karşımıza sadece iki adet metafor çıkmaktadır. Bu kategoriye ait metaforlar şu şekildedir:

Kurum müdürünün ögrretmene davranışl teraziye benzer, çünkü her ögretmene adaletli olmalıdır.

Kurum müdürünün öğretmene davranışı arabaya benzer, çünkü öğretmenin performansına göre hızını, gazını ayarlamak durumundadır.

Öğretmenlerin zihinlerindeki ideal müdür alg1sı, bir terazi gibi hassas ve adaletli olmayı gerektirmektedir. Adaletli bir müdür çalışanlarına eşit mesafededir ve hiçbirini bir diğerine karşı dezavantajlı bir pozisyona yerleştirmez.

Sert alt kategorisi incelendiğinde, beş farklı katılımcı tarafindan üretilen beş farklı metafor karşımıza çıkmaktadır. Bu kategoriye ait metaforlar şu şekilde örneklendirilebilir:

Kurum müdürünün ögrretmene davranışl ayvaya benzer, çünkü öğretmenlerine tatlı sert olmalıdir.

Kurum müdürünün öğretmene davranışı kayalık gibi olmalıdır, çünkü sert ve dik olmalıdır. Otorite için bu gereklidir.

Aracı alt kategorisi incelendiğinde, karşımıza sadece bir adet metafor çıkmaktadır. $\mathrm{Bu}$ kategoriye ait metafor şu şekildedir:

Kurum müdürünün ögrretmene davranışı hakeme benzemeli, çünkü üst yönetim ve ögretmenler arasinda köprü olmalıdır.

\section{Sonuç}

Örgün eğitim kurumlarında müdürlerin davranışlarını ve öğretmenlerin müdür algılarını inceleyen çeşitli çalışmalar yapılmış olmakla birlikte, yaygın eğitim kurumlarında benzer çalışmaların sayısı oldukça azdır. Müdür davranışı ve öğretmen algısını fenomenolojik açıdan inceleyen çalışmaların sayısı ise oldukça sınırlıdır. Bu araştırmada İstanbul Büyükşehir Belediyesi Sanat ve Meslek Eğitimi Kursları'nda (İSMEK) görev yapan öğretmenlerin müdür kavramına ilişkin zihinsel algıları metaforlar aracılığı ile tespit edilmek istenmiştir. Araştırmaya İSMEK bünyesinde farklı branşlarda istihdam edilen 180 öğretmen katılmıştır. Nitel araştırma metodolojisine göre tasarlanan bu çalışmada, kurum müdürlerinin öğretmenlere yönelik davranışları ve öğretmenlerin müdür algıları üzerine zengin bulgular elde edilmiştir.

Araştırma bir yandan öğretmenlerin mevcut müdürlerine ilişkin algılarını keşfetmeye çalışmış, diğer yandan da ideal müdür algılarının alt boyutlarını ortaya koymuştur. Kurum müdürlerinin kimisi yumuşak, kibar, anlayışlı davranırken kimisi; sert, dengesiz ve iğneleyici davranışlarda bulunmaktadırlar. Öğretmenlerin ideal müdür algıları ise 
var olan uygulamaların da etkisiyle hem iyi huylu, hem koruyan ve geliştiren, hem de sert müdür alt boyutlarını içermektedir.

İSMEK kurslarında görev yapan öğretmenlerin mevcut müdürleri ile ilgili algıları \% 60 oranında pozitiftir. Müdürleri onlara iyi davranmakta ve akademik gelişimlerini desteklemektedirler. Aynı kurumlarda müdürlere yönelik algıların \% 40 ise olumsuzdur. $\mathrm{Bu}$ olumsuzluk en çok, müdürün öğretmenlerini duygusal olarak rahatsız etmesinden, agresif ve değişken tutum ve davranışlarından kaynaklanmaktadır.

Öğretmenlerin müdürlerine yönelik olumlu algılarına ilişkin şunlar söylenebilir:

I. Öğretmenlerin müdürlerine ilişkin olumlu algıları arasında en öne çıkan, iyi davranan ve iyi hissettiren yönetici imajıdır. Müdürler öğretmenlerine değer vermekte, onları rahatlatan davranışlar sergilemektedir. Bu algı sadece iyi davranışlarla değil iyi bir sözlü iletişimle de sağlanmaktadır.

II. İkinci en güçlü pozitif imaj, geliştiren müdüre ait metaforlardır. Araştırmamız göstermektedir ki; öğretmenler müdürlerini onları geliştiren, yönlendiren, daha iyi bir noktaya taşımaya çalışan yöneticiler olarak algılamaktadırlar. Yönetici sadece işlerin zamanında ve doğru bir biçimde tamamlanmasını sağlayan kişi değildir. Yönetici işi tamamlarken ekibini de daha iyiye doğru cesaretlendiren kişidir.

III. Koruyuculuk, pozitif müdür algısının üçüncü güçlü bileşenidir. Katılımcılara göre müdürleri her zaman yanlarında durmakta, onları zor durumlarda koruyup kollamakta, üstlerine ve dışarıya karşı savunmaktadır.

IV. Öğretmenlerden az bir kısmı idarecilerinin bütün çalışanlara eşit mesafede durduklarını, adaletli davrandıklarını vurgulamışlardır.

V. Vurgulanması gereken bir diğer nokta ise müdürün kurumun başarısı ya da başarısızlığı üzerindeki etki gücüdür. Öyle görünmektedir ki; katılımcılardan bir kısmı için müdürleri muktedirdir. Bir başka ifadeyle başarının ya da başarısızlığın esas sorumlusu müdürlerdir.

Öğretmenlerin müdürlerine ilişkin olumsuz algılarını değerlendirmemiz gerekirse;

I. Müdürün söz ve davranışlarıyla öğretmenlerini iğnelemesi, ağır sorumluluklar vermesi ve hiç takdir etmemesi öğretmenlerin zihinlerinde yöneticilerine ilişkin olumsuz bir algı yaratmaktadır. Diğer alt kategorilerden farklı olarak burada öğretmenlerin duygusal incinmişlikleri ön plandadır.

II. Kurum yöneticisinin istikrarlı olmayan davranışları öğretmenler tarafından borsa, tsunami, pilates topu, politikacı ve meterolojiye benzetilmiştir. Eğitim kurumu içerisinde bir müdürün bu tarz dengesiz tutumlarıöğretmenler tarafından negatif bir özellik olarak algılanmaktadır. 
III. Öğretmenlerinzihinlerindekikurummüdürüneaitnegatifimajlar danbirtanesi de müdürlerinagresifolmalarıdır. Ne zaman sinirleneceği belli olmayan, eleştirikabuletmeyen, öfkesinikontroledemeyenyöneticilerekiplerind eolumsuzbiralgıluşturmuşlardır. Bu olumsuzalgı hem kurumkültürünü, hem performansiolumsuzetkileyebilir.

IV. Öğretmenler müdürlerinin buyurgan tutumlarından rahatsız olmaktadırlar. Sürekli emirler veren ve emirlerine sorgusuz sualsiz itaat bekleyen müdürler, çalışanlarının zihinlerinde olumsuz bir yönetici algısı yaratmaktadır.

V. Araştırma sonuçları göstermektedir ki; müdürlerin kimi davranışlarından ötürü öğretmenler kendilerini oldukça değersiz hissetmekte ve bu tutumları olumsuz algılamaktadırlar. Bazen yapılan işin küçümsenmesi bazen de as üst ilişkisindeki dengesizlikler, öğretmenlerin zihinlerinde olumsuz algilara sebebiyet vermektedir.

VI. Öğretmenler yöneticilerinin işlerin zamanında tamamlanması hususunda esnek olmadıklarından, hatta oldukça katı olduklarından şikâyet etmektedirler. Bu durum onların zihinlerinde yöneticileri ile ilgili olumsuz bir algı oluşturmaktadır.

VII. Yönetici yetkisini kullanarak çalışanlarını cezalandırabilir. Bu cezalandırma yetkisi kötüye kullanıldığında ise, öğretmenlerin zihinlerindeki olumsuz müdür algisına yeni bir boyut eklemiş oluruz.

$\mathrm{Bu}$ çalışma kapsamında pozitif ve negatif yönleri ile ortaya çıkan müdür algısını, benzer çalışmalarla kıyaslamadan önce belirtmemiz gereken birkaç nokta vardır. Birincisi mevzubahis diğer çalışmalar analiz birimi olarak müdürlük makamını almışlardır. Oysa bizim çalışmamızın odağı kurum müdürünün öğretmenlere yönelik davranışlarıdır. Ayrıca sıralayacağımız çalışmalardan yalnızca birisi hâlihazırda öğretmen olanlarla yürütülmüşken, diğerleri öğretmen adayları üzerinden gerçekleştirilmiştir.

Korkmaz ve Çevik (2018) tarafından gerçekleştirilen ortaokul öğretmenlerinin müdür algılarına yönelik araştırmadaki;

a. Denetleyici ve Güç Unsuru Olarak Müdür, çalışmamızdaki Cezalandıran Müdür

b. Değişken Biri Olarak Müdür, çalışmamızdaki Değişsken Müdür

c. Koruyucu ve Güven Verici Müdür, çalışmamızdaki Koruyan Müdür

d. Yol Gösterici ve Lider Biri Olarak Müdür, çalışmamızdaki Gelişstiren Müdürkategorileriyle benzeşmektedir. 
Akyol ve Kapçak’ın (2017) öğretmen adayları üzerinde yaptıkları araştırmada ortaya koydukları

a. Koruyucu (Protector), çalışmamızdaki Koruyan

b. Rehber (Guide), çalışmamızdaki Geliştiren

c. Yeri Doldurulamaz Kişi (IrreplaceablePerson), çalışmamızdaki

\section{Muktedir}

d. Adalet Sembolü (Figure of Justice), çalışmamızdaki Adaletli / Şeffaf kategorileriyle uyuşmaktadır.

Öğretmen adayları ile yürütülen bir başka çalışmanın (Çobanoğlu ve Gökalp, 2015) bizim çalışmamızla benzeşen sonuçları ise şu şekildedir:

a. Koruma, çalışmamızdaki Koruyan kategorisine

b. Ana Unsur, çalışmamızdakiMuktedirkategorisine

c. Eğiticilik, çalışmamızdaki Geliştiren kategorisine

d. Baskıcılık, çalışmamızdaki Buyurgan kategorisine

e. Düzenlilik, çalışmamızdaki Temiz / Tertipli kategorisine benzeşmektedir.

Son olarak, sınıf öğretmeni adaylarına uygulanan bir araştırmada (Tüzel ve Kalyon, 2012) elde edilen

a. Koruma kollama, çalışmamızdaki Koruyan kategorisine

b. Okul başarısına etkisi, çalışmamızdakiMuktedirkategorisine

c. Emir Verme / Katı Kuralcılık, çalışmamızdaki Buyurgan kategorisine

d. Ĕ̌itim Liderliği/Rehberlik, çalışmamızdakiGeliştiren kategorisine benzeşmektedir.

Karşılaştırmalar göstermektedir ki; farklı araştırmalar öğretmenlerin ya da öğretmen adaylarının müdürlerine yönelik benzer algılarını keşfedebilmiştir. Çalışmamız kapsamında elde ettiğimiz kategoriler arasında, öncelikli olarak Koruyan, Geliştiren, Muktedir ve Buyurgankategorileri başka çalışmalarla da desteklenmektedir.

İSMEK kurslarında öğretmenlik yapan eğitimcilerin ideal öğretmen algıları da dikkate değerdir. Öğretmenler müdürlerinden tecrübeleri ile onlara yol göstermelerini, kişisel gelişimlerine ve kariyerlerine destek olmalarını beklemektedirler. Öğretmenlerin zihinlerinde yol gösteren, destekleyen bir ideal müdür algısı vardır. Öğretmenlerin 
zihinlerindeki ideal müdür algılarına ilişkin bir diğer özellik ise, müdürün ekibine değer vermesi, onların üzerine titremesidir. Öğretmenlerin gözünde iyi bir as-üst ilişkisi altın değerindedir. Ortaya güzel işler çıkarmak isteyen bir müdür ancak öğretmenlerine hak ettikleri değeri verirse başarılı olabilecektir.

Ayrıca, öğretmenler müdürlerini sadece bir yönetici, kurumlarını da para kazandıkları bir yer olarak algılamamaktadırlar. İdareciler çalışanlarına şefkat, merhamet ve anlayış göstermeli, kurumlarını bir aile sıcaklığında yönetmelidirler. Huzurlu bir ortamda çalışan öğretmenler şüphe yok ki yüksek motivasyon ve yüksek performans göstereceklerdir. Öğretmenlerin zihinlerindeki ideal müdür algısı, bir terazi gibi hassas ve adaletli olmayı da gerektirmektedir. Adaletli bir müdür çalışanlarına eşit mesafededir ve hiçbirini bir diğerine karşı dezavantajlı bir pozisyona yerleştirmez.

İdeal müdür algısının en güçlü bileşenlerine öncelik verirsek; ideal müdür, öğretmenlerine iyi davranan, onları koruyan ve aynı zamanda sert olabilen bir yöneticidir. Eğitim kadrosu ile insani bir ilişki geliştirdikten sonra müdürden beklenen en önemli şey, öğretmenlerini üst yönetimden, şikâyetlerden ve yaptırımlardan bir avukat ya da bir şemsiye gibi korumasıdır. Ancak bütün bu iyi huyluluğa bir sertlik de eşlik etmelidir.

Araştırma İstanbul Büyükşehir Belediyesi bünyesindeki yaşam boyu öğrenme merkezleri olan İSMEK'lerde uygulanmıştır. Daha kapsamlı sonuçlar elde edebilmek için araştırma, belediyeler ya da üniversiteler bünyesindeki diğer yaşam boyu öğrenme merkezlerinde yinelenebilir. Araştırmanın sınırlılığı gibi görünen bu husus aynı zamanda çalışmanın homojen bir grup üzerinde yapılmasına olanak sağladığından, çalışmanın güçlü bir yanı olarak da kabul edilebilir.

\section{Kaynakça}

Akan, D., Yalçın, S., ve Yıldırım, İ. (2014). “Okul Müdürü” Kavramına İlişkin Öğretmenlerin Metaforik Algıları. Illköğretim Online, 13(1), 169-179.

Akyol, B., ve Kapçak, C. B. (2017). Pre-service Teachers' Perceptions of Administration and School Principal Reflected Through Metaphors. European Journal of Education Studies, 3(10), 293-309. https://doi.org/10.5281/zenodo.1009723

Balc1, A. (2008). Örgüt Mecazları. Ankara: Pegem Akademi.

Başar, H. (2000). Eğitim Denetçisi (5. Bask1). Pegem Akademi.

Bursalığlu, Z. (2016). Eğitim Yönetiminde Teori ve Uygulama (13. Bask1). Pegem Akademi.

Çelik, V. (2003). Eğitimsel Liderlik. Ankara: Pegem Akademi.

Çelikten, M. (2004). Bir Okul Müdürünün Günlüğü. Fırat Üniversitesi Sosyal Bilimler Dergisi, 14(1), 123-135.

Cerit, Y. (2008). Öğretmen Kavramı ile İlgili Metaforlara İlişkin Öğrenci, Öğretmen ve Yöneticilerin Görüşleri. Türk Eğitim Bilimleri Dergisi, 6(4), 693-712. 
Çobanoğlu, N., ve Gökalp, S. (2015). Öğretmen Adaylarının Okul Müdürüne İlişkin Metaforik Algıları. Mustafa Kemal Üniversitesi Sosyal Bilimler Enstitüsü Dergisi, 12(31), 279-295.

Creswell, J. W. (2017). Eğitim Araştırmaları: Nicel ve Nitel Araştırmanın Planlanması, Yürütülmesi ve Değerlendirilmesi. (H. Ekşi, Ed.). İstanbul: Edam.

Demirtaş, H., ve Özer, N. (2014). Okul Müdürlerinin Bakış Açısıyla Okul Müdürlüğü. Kastamonu Eğitim Dergisi, 22(1), 1-24.

Drucker, P. F. (1973). Management: Tasks, Responsibilities, Practices. New York: TRUMAN TALLEY BOOKS $/$.

Eraslan, L. (2011). Sosyolojik Metaforlar. Akademik Bakış Dergisi, 1-22.

Helvacı, M. A., ve Aydoğan, İ. (2011). Etkili Okul ve Etkili Okul Müdürüne İlişkin Öğretmen Görüşleri. Uşak Üniversitesi Sosyal Bilimler Dergisi, 4(2), 42-61.

Hoy, W. K., ve Miskel, C. G. (2012). Educational Administration Theory, Research and Practice. (S. Turan, Ed.). Ankara: Nobel.

Korkmaz, M., ve Çevik, M. S. (2018). Ortaokul Öğretmenlerinin Müdür Kavramına İlişkin Metaforik Algıları. Kuramsal Eğitimbilim Dergisi, 11(4), 973-1002.

Korkmazyürek, H., ve Hazır, K. (2017). Alg1, Tutum ve Duyular. In Ü. Sığr1 ve S. Gürbüz (Eds.), Örgütsel Davranı̧̧ (4. Baskı).

Lashway, L. (2003). Role of School Leader: Trends and Issues. Journal of Curriculum and Supervision, 18(3), 240-258.

Leithwood, K. (2005). Understanding successful principal leadership: progress on a broken front. Journal of Educational Administration, 43(6), 619-629. https://doi. org/10.1108/09578230510625719

Metafor. (n.d.). In Türk Dil Kurumu Sözlükleri. Retrieved from https://sozluk.gov.tr/

Morgan, G. (1998). Yönetim ve Örgüt Teorilerinde Metafor. (G. Bulut, Ed.). İstanbul: Mess Yayınlar1.

Okutan, M. (2016). Eğitim Yönetimi ve Denetiminde Örnek Olaylar (2. Bask1). Pegem Akademi.

Örücü, D. (2014). Öğretmen Adaylarının Okul, Okul Yönetimi ve Türk Eğitim Sistemine Yönelik Metaforik Alg1ları. Educational Administration: Theory and Practice, 20(3), 327-358. https:// doi.org/10.14527/kuey.2014.014

Sackmann, S. (1989). The Role of Metaphors in Organization Transformation. Human Relations, 42(6), 463-485. Retrieved from https://doi.org/10.1177/001872678904200601

Scheerens, J., ve Stoel, W. G. R. (1988). Development of Theories of School-Effectiveness. In The Annual Meeting of the American Educational Research Association.

Şimşek, H., ve Yıldırım, A. (2018). Sosyal Bilimlerde Nitel Araştırma Yöntemleri. Ankara: Seçkin Yayıncilik.

Şişman, M., ve Turan, S. (2005). Eğitim ve Okul Yönetimi. In Y. Özden (Ed.), Eğitim ve Okul Yöneticiliği El Kitabı. Pegem Akademi.

Sı̆̆rı, Ü. (2018). Nitel Araştırma Yöntemleri. Beta.

Taymaz, H. (2019). Okul Yönetimi (11. Bask1). Pegem Akademi. 
Tosun, F. Ç. (2018). Perceptions of Prospective Teachers About School Principals: Prejudice or Real? International Journal of Progressive Education, 14(2), 106-120. https://doi.org/10.29329/ ijpe.2018.139.8

Tsoukas, H. (1991). The Missing Link: A Transformational View of Metaphors in Organizational Science. The Academy of Management Review, 16(3), 566. https://doi.org/10.2307/258918

Turan, S., Yıldırım, N., ve Aydoğdu, E. (2012). Okul Müdürlerinin Kendi Görevlerine İlişkin Bakış Açıları. Pegem Ĕ̈itim ve Öğretim Dergisi, 2(3), 63-76.

Tüzel, E., ve Kalyon, D. Ş. (2012). Sınıf Öğretmeni Adaylarının Okul Yöneticilerine İlişkin Metaforları. Turkish Studies, 12(33), 501-522.

Tüzel, E., ve Şahin, D. (2014). İlköğretim Birinci Kademe Öğrencilerinin Okul Yöneticilerine İlişkin Metaforları. Adıyaman Üniversitesi Sosyal Bilimler Enstitüsü Dergisi, 7(17), 355-396.

Uğurlu, C. T., ve Abdurrezzak, S. (2016). Research of Teachers' Views on Effective School and School Leadership. Educational Administration: Theory and Practice, 22(3), 401-428. https:// doi.org/10.14527/kuey.2016.016

Yalçın, M., ve Erginer, A. (2014). İlköğretim Okulu Öğrencilerinin Okul Müdürü Algılarına İlişkin Yaptıkları Çizimler. Eğitim ve Bilim, 39(171), 270-285.

Yıldırım, N., ve Uğur, M. (2011). Öğrencilerin Algısından Okul Müdürü İmgelerinin Karikatürize İfadeleri. Kastamonu Eğitim Dergisi, 19(2), 409-426. 